\title{
PENERAPAN IOT (INTERNET OF THING) UNTUK MONITORING ONLINE PENGGUNAAN KADAR INFUS DAN KONDISI PASIEN YANG SEDANG MEMBUTUHKAN PERAWATAN
}

\author{
Achmat Fahrul Taufiqurrohman, Suryo Adi Wibowo, F.X Ariwibisono. \\ Program Studi Teknik Informatika S1, Fakultas Teknologi Industri \\ Institut Teknologi Nasional Malang, Jalan Raya Karanglo km 2 Malang, Indonesia \\ achmatfahrul24@gmail.com
}

\begin{abstract}
ABSTRAK
Cairan infus adalah air yang dimurnikan lewat proses penyulingan. Pemberian cairan melalui infus merupakan tindakan memasukkan cairan melalui intravena untuk memenuhi kebutuhan cairan dan elektrolit serta sebagai tindakan pengobatan dan pemberian makanan. Cairan infus juga digunakan sebagai larutan awal bila status elektrolit pasien belum diketahui, misal pada kasus dehidrasi karena asupan oral tidak memadai, demam, dan lain-lain. Dalam perkembangan teknologi robot yang sangat pesat saat ini, banyak perkembangan ini dapat dilihat dari teknologi mikrokontroler yang merupakan suatu terobosan teknologi mikroprosessor dan mikrokomputer. Dan juga masih banyaknya pihak rumah sakit melakukan pemantauan cairan infus pasien secara manual dan berkala.

Dengan adanya perkembangan teknologi ini pihak rumah sakit sudah dapat memantau kondisi pasian hanya melalui ruang perawat di layar monitor computer yang berbasis website, yang dimana semua data tertera, antara lain, pasien dengan nama siapa, kamar dimana, dan kondisi pasien nya bagaimana. Di dalam pengembangan ini memiliki banyak fiur yang dapat membantu penggunan awam seperti perawat dimana didalam website tersebut sudah terdapat fitur dengan tabel yang dapat berubah warna sesuai dengan keadaan pasien, dimana ada warna merah, kuning, dan hijau. Warna merah menandakan kondisi pasien harus segera ditangai untuk pergantian infus atau cek kondisi pasien, warna kuning menandakan kondisi infus pasien akan segera habis karena sisa kadar infusnya 100 gram ke bawah, sementara warna hijau menandakan kondisi pasiean sedang baik-baik saja. Sementara fitur lainnya ada halaman riwayat data pasien untuk melihat data pasien siapa saja yang telah dirawat serta sebagai arsip rumah sakit, dan yang terakhir ada halaman tambah data pasien untuk pasien yang baru dating.

Hasil pengujian fungsional menunjukkan hasil $100 \%$, artinya semua fitur program dapat berjalan sesuai dengan fungsinya. Hasil pengujian alat menunjukkan hasil $100 \%$, artinya semua sensor bisa bekerja sesuai fungsinya. Hasil pengujian dari Load Cell sensor, prosentase error rata-rata sensor berat (load cell) menunjukkan nilai $=6,626 \%$, sedangkan untuk nilai prosentase error tertinggi menunjukkan nilai $=8,67 \%$. Hasil pengujian dari Heart Rate sensor, prosentase error rata-rata sensor heart rate menunjukkan nilai $=7,4 \%$, sedangkan untuk nilai prosentase error tertinggi menunjukkan nilai $=10 \%$. Hasil pengujian dari Temperatuter sensor, prosentase error rata-rata sensor heart rate tertinggi menunjukkan nilai $=5,104 \%$, sedangkan untuk nilai prosentase error tertinggi menunjukkan nilai $=7 \%$. Dari pengujian sistem, sistem dapat di jalankan pada sistem operasi Windows. Dari pengujian sistem dapat berjalan dengan baik menggunakan bahasa pemrograman PHP, MySQL dan PhpMyadmin sebagai database. Dan dari pengujian fungsional sistem, sistem dapat di jalankan pada 3 browser berbeda. Antara lain : Brave Browser, Google Chrome, Microsoft Egde
\end{abstract}

Kata Kunci : Monitoring, IOT, Infus, Heart Rate, Oksigen, Web

\section{PENDAHULUAN}

Keterlambatan perawat dalam penggantian cairan infus dapat memberikan dampak negatif terhadap pasien dengan terjadinya komplikasi seperti darah pasien tersedot naik ke selang infus dan dapat membeku pada selang infus, sehingga mengganggu kelancaran aliran infus. Selain itu, jika tekanan pada infus tidak stabil, darah yang membeku pada selang infus dapat tersedot kembali masuk ke dalam pembuluh darah. Darah yang membeku (blood clot) tersebut dapat beredar ke seluruh tubuh dan dapat menyumbat kapiler darah di paru-paru sehingga menyebabkan emboli di paru-paru.

Hal ini tentunya sangat membantu berbagai pihak mulai perorangan, hingga lembaga kesehatan utamanya rumah sakit umum. Teknologi robotika memiliki peluang besar untuk merevolusi industry medis, sehingga dapat mempemudah petuga rumah sakit dalam memantau kadar infus yang sedang digunakan oleh pasien dengan mudah dan efisien dengan teknologi sensor yang semakin pesat perkembanganannya. Dengan adanya sensor yang digunakan untuk system penerapan ini yaitu sensor Load Sell yang dapat mendeteksi berat infus, dan sensor heart rate untuk deteksi denyut nadi dan detak jantung dengan bertujuan ketika dilakukan pengukuran 'Resting Heart Rate' (RHR) sebagian orang memiliki capaian yang berbeda-beda.

Penerapan ini juga akan membantu Dinas Kesehatan sebagai wadah yang menaungi lembaga kesehatan dalam mengurangi kasus keteledoren petugas rumah sakit dalam penggantian cairan infus. 
Dapak positif yang akan dirasakan dalam perawatan pasien dirumah sakit secera keselurahan adalah Perawatan Pasien Di Klinik/Puskesmas/Rumah dapat terawat dengan Baik, Cepat, Efektif dan Efisien. Sehingga mengurangi akan kematian akan keteledoran jangka waktu pergantian infus pada pasien.

\subsection{Rumusan Masalah}

Mengacu pada permasalahan diatas, maka dapat dirumuskan masalah sebagai berikut:

1. Bagaimana mengembangkan system monitoring kadar infus berdasarkan berat dan label pada pasien berplatform website?

2. Bagaimana membuat system monitoring online kadar infus pada pasien dengan sederhana, efesien, dan efektif?

3. Bagaimana membuat system monitoring online denyut nadi dan detak jantung pada pasien secara akurat dan cepat?

\subsection{Batasan Masalah}

Agar tidak terjadi penyimpangan, maksud dan tujuan utama penyusunan skripsi ini maka perlu diberikan batasan masalah, antara lain:

1. Sensor yang digunakan ada 3, antara lain sensor berat (Load Cell), Heart Rate sensor, sensor Temperature

2. Data yang digunakan berupa data digital yang merupakan range dari masing-masing sensor, Heart Rate datanya bersatuan BPM (beats per minute), Load Cell berupa gram, dan Temperature berupa persen $(\%)$

3. Hanya memfokuskan pengembangan penerapan system ke dalam system operasi windows berbasis platform website.

4. Bahasa pemrograman yang digunakan yaitu $\mathrm{C}$ arduino untuk arduino. HTML, PHP, Jquery dan Javascript untuk website dengan menggunakan database Mysql 5.3.2

5. Hanya membahas tentang sistem operasi windows.

6. Cadangan peringatan menggunakan buzzer

7. Tidak membahas secara rinci tentang segala jenis infus.

8. Tidak membahas kejanggalan selain system monitoring

\subsection{Tujuan}

Adapun tujuan dari pengembangan ini adalah:

1. Pengembangan system monitoring kedalam system operasi windows, berplatofrm website untuk lebih memudahkan pengguna dalam memantau dan memperoleh data kadar infus pasien sesuai ruangan pasien.

2. system monitoring online kadar infus yang sederhana, efesien, dan efektif ialah friendly user, minimalis dan mudah dipahami oleh pengguna

\subsection{Luaran Yang Diharpkan}

1. Dapat mempermudah kinerja petugas rumah sakit dalam mengkontrol kadar infus pada pasiean disetiap ruangan sehingga tidak sampai terjadi gagal jantung, stroke, hingga kematian.

2. Pengambilan informasi data kadar infus yang akurat dan efektif sehingga tidak ada terjadi keteledoran dalam pergantian cairan infus pasien, agar tidak sampai terjadi kematian pasien yang sepenuhnya ditangani oleh perangkat yang informasinya langsung tampil diwebsite sehingga tidak menyulitkan penggguna.

\section{TINJAUAN PUSTAKA}

\subsection{Penelitian Terdahulu}

Priyanto (2015) pada penelitian dengan judul "Sistem Informasi Monitoring Perkuliahan Berbasis Web di STMIK Sinar Nusantara Surakarta". Tujuan penelitian ini yaitu dalam proses monitoring pelaksanaan perkuliahan dapat lebih terkontrol dan lebih uptodate karena melibatkan kesatuan luar yang terhubung dalam sebuah sistem. Sistem Informasi monitoring perkuliahan ini memiliki kesamaan dengan yang akan penulis buat. Adapun persamaan dari penelitian ini tentu sama-sama menggunakan sistem website dan yang menjadi perbedaan dengan sistem yang dibuat Priyanto, adalah sistem yang dibuat penulis memonitoring kegiatan mentoring.

Idris (2016) pada penelitian selanjutnya dengan judul“ Efektifitas Sistem Informasi Pelaporan Monitoring dan Evaluasi (e-controlling) pada Bagian Evaluasi Pembangunan Sekretariat Daerah Kota Bontang". Tujuan penelitian ini adalah untuk menganalisis efektifitas sistem informasi pelaporan monitoring dan evaluasi (econtrolling) pada bagian evaluasi pembangunan sekretariat daerah Kota Bontang dan yang kedua adalah untuk menganalisis faktor pendukung dan penghambat dalam efektifitas sistem informasi pelaporan monitoring dan evaluasi (e-controlling) pada bagian evaluasi pembangunan sekretariat daerah Kota Bontang. Adapun persamaan dari penelitian ini tentu sama-sama membuat sistem monitoring dan yang menjadi perbedaan dengan sistem yang dibuat Idris, adalah aplikasi yang dibuat penulis hanya memantau kegiatan mentoring.

Risnandar (2015) pada penelitian selanjutnya dengan judul “ Pembuatan Aplikasi Sistem Informasi Monitoring Kegiatan Mahasiswa Berbasis Web dan Android Client". Tujuan penelitian ini adalah untuk monitoring kegiatan mahasiswa . Adapun persamaan dari penelitian ini yaitu sama-sama membuat aplikasi monitoring berbasis web. Yang menjadi perbedaan dengan sistem yang dibuat Risnandar adalah, aplikasi yang dibuat penulis hanya berbasis web.

Adi Wibowo (2019) pada penelitian dengan judu "Ruang Kuliah Pintar Pemantau Tingkat Efektivitas Pembelajaran Yang Dapat Mendeteksi Mahasiswa Bosan Dan Mengantuk" tujuan penelitian ini adalah Teknologi Internet of Things (IoT) dapat diterapkan pada presensi menggunakan RFID, dimana dengan teknologi ini data presensi dapat dilihat oleh guru, administasi, orang tua dan siswa secara real time dan online, sehingga jika siswa 
membolos dapat diketahui dengan cepat oleh orang tua dimanapun mereka berada, pengenalan wajah dan pendeteksi siswa yang mengatuk akan dipergunakan untuk melakukan evaluasi tingkat efektifitas pembelajaran, sehingga jika terjadi proses pembelajaranyang kurang tepat dapat segera dilakukan perbaikan untuk memperoses sistem pembelajaran yang lebih maksimal.

\subsection{Dasar Teori}

\subsubsection{Sistem Monitoring}

Didefinisikan sebagai siklus kegiatan yang mencakup pengumpulan, peninjauan ulang, pelaporan, dan tindakan atas informasi suatu proses yang sedang diimplementasikan.

\subsubsection{Sensor Berat (Load Cell)}

Sel Beban atau Load Cell adalah jenis sensor yang digunakan untuk mengukur berat. Input dari Load Cell ini adalah gaya atau tekanan sedangkan outputnya adalah nilai tegangan listrik. Ada beberapa jenis Load Cell, diantaranya adalah Beam Load Cell, Single Point Load Cell dan Compression Load Cell Sensor berat ditunjukkan pada Gambar 1.

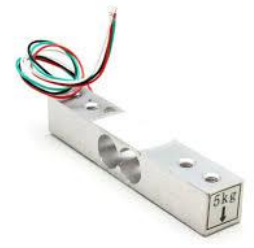

Gambar 1. Sensor berat

\subsubsection{Pulse Heart Rate Sensor}

Pulse Heart Rate Sensor adalah sebuah sensor denyut jantung. Sensor ini dapat mendeteksi denyut nadi pada jari telunjuk tangan dengan cara menggabungkan data denyut nadi dari sensor dengan program di mikrokontroler bisa di dapatkan nilai bpm,Heart rate sendiri merupakan detak jantung per satuan waktu yang biasanya dinyatakan dalam beats per menit (bpm). Sensor heartrate ditunjukkan pada gambar 2.

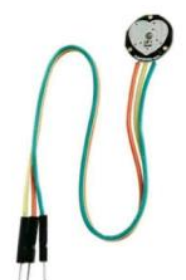

Gambar 2. Sensor Heart Rate

\section{METODE PENELITIAN}

\subsection{Internet Of Things (IOT)}

IoT merupakan Sebuah konsep dimana suatu objek yang memiliki kemampuan untuk mentransfer data melalui jaringan tanpa memerlukan interaksi manusia ke manusia atau manusia ke komputer Penggunaan IoT dapat diimplementasikan pada berbagai hal salah satunya adalah perkuliahan., pelanggan, dan sebagainya yang dapat diakses dari basis data perusahaan.

\subsection{Blok Diagram Sistem}

Sensor berat dan sensor detak jantung berserta denyut nadi yang terdapat pada infus itu lah yang akan mengirimkan data kadar infus yang sedang digunakan oleh pasien disteipa ruangan. Dibantu nantinya NodeMcu sebagai penghubung sensor dengan database sehingga data yang keluarkan dapat lancar dan akurat sehingga tidak ada kekeliruan dalam data yang mucul di website diruangan petugas rumah sakit.

Adapun alat pembatu lain yakni buzzer yang digunakan ketika indikator infus sudah mau habis dan sudah habis jadi nanti ada tanda peringatan dengan berbunyi dengan penjelasan diatas, ketika mau habis dan sudah habis sebagai tanda untuk waktu pergantian infus. Proses kerja pada alat ini di tunjukkan pada Gambar 3

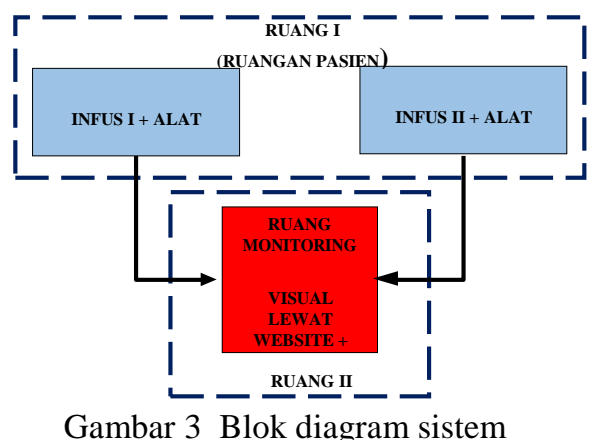

\subsection{Flowchart Sistem}

Flowchart sistem ini menjelaskan proses berjalananya aplikasi seperti ditunjukkan pada Gambar 4.

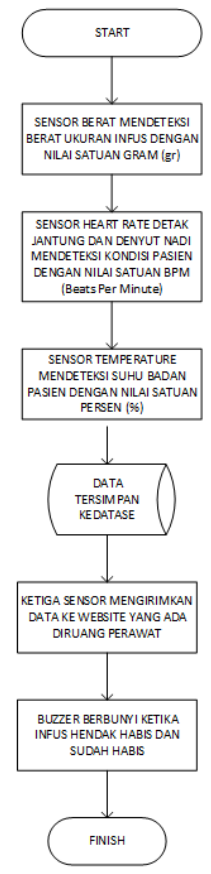

Gambar 4 Flowchart Sistem 
Berdasarkan flowchart pada Gambar 4, Pertama sensor berat mendeteksi ukuran infus dan jenis labelnya, kemudian pulse heart sensor mendeteksi dentak jantung dan denyut nadi kondisi pasiean yang dirawat. Setelah itu data dari sensor tersimpan ke database website dengan bantuan NodeMCu agar datanya akurat dan lancar yang akan dimunculkan setelah itu yang ada ruang monitor ruang perawat.

Selanjutnya setelah data muncul ke layar website seketika indicator infus sudah mau habis buzzer akan berbunyi dan ketika infus sudah habis buzzer akan berbunyi lagi sebagai tanda waktunya pergantian infus untuk pasiean diruang mana yang waktunya ganti.

\subsection{Rangkaian prototype desain alat}

Gambar rangkaian prototype desain alat ini merupakan rangkaian dari penilitian pengembengan teknologi mikrokontroler.

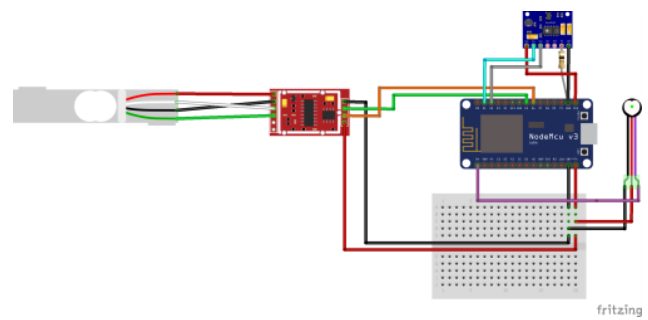

Gambar 5. Rangkaian prototype desain alat

Dari gambar 5. rangkaian diatas ada beberapa alat yang saya gunakan, antara lain yaitu, Arduino, NodeMcu, load cell sensor berfungsi mendeteksi berat kadar ifnus pasien, dan heart rate sensor berfungsi mendeteksi denyut nadi/detak jantung pasien, dan sensor temperature berfungsi mendeteksi suhu badan pasien

\section{HASIL DAN PEMBAHASAN \\ 4.1 Hasil}

Tahap implementasi software pada platform website yaitu tahap penerapan sistem pada website untuk monitoring alat agar dapat dipantau secara optimal. Desain website yang di buat pada tahap prototype, di implementasikan menjadi bentuk halaman website yang dibuat menggunakan perangkat lunak yang dijelaskan pada analisis kebutuhan. Untuk hasil website monitoring pada infus dan kondisi pasien telah dibuat sesuai dengan rancangan yaitu terdiri dari 3 halaman, diantaranya Halaman Monitoring untuk monitoring data real time pada alat, Halaman Riwayat untuk menampilkan riwayat data pasiean. Dan yang terkahir halaman tambah data dan edit untuk penambahan data pasien yang baru datang. Untuk penempatan menu yang digunakan untuk mengakses halaman lain ada di bagian Sidebar untuk membuat halaman fokus pada komponen monitoring. Adapaun implementasi software ditunjukkan pada Gambar 6.

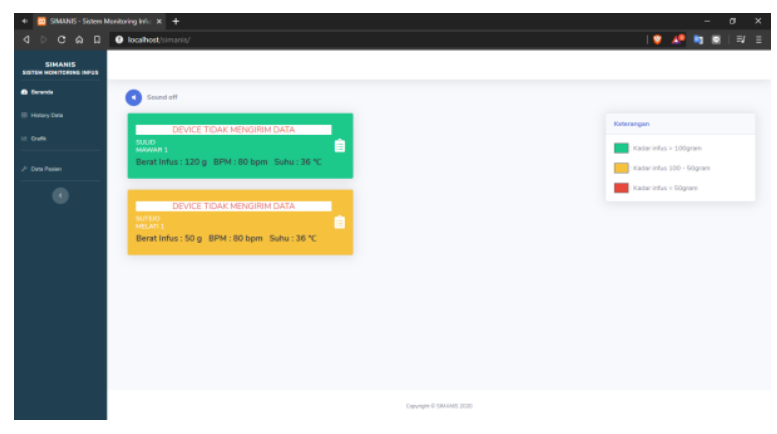

Gambar 5. Implementasi Software

Gambar 5. Merupakan implemntas softaware system monitoring infus dan kondisi pasien, yang dimana disana sudah tertera inormasi nilai range kondisi pasien dari hasi deteksi sensor, dimana dengan ambang batas dari berat infus, jika kondisi berat infus kurang dari 100 gram maka indikasi warna berubah warna merah, jika sama dengan 100 maka indikasi warna berubah warna kuning, dan jika lebih dari 100 maka akan menjadi warna hijau.

\subsection{Pengujian Hardware}

Untuk fungsi monitoring pada alat terdapat sensor berat untuk mendeteksi berat kadar infus, sensor heartrate untuk mendeteksi denyut nadi/detak jantung pasien, dan untuk sensor Pulse Oximeter Biosensor mendeteksi kadar okesigen pasiean, lalu modul wifi mengirimkan data sensor ke website dengan bantuan wifi untuk disimpan di database dan ditampilkan pada website yang semua datanya telah terhubung dan diolah oleh mikrokontroler nodeMCU. Adapaun implementasi hardware ditunjukkan pada Gambar 7

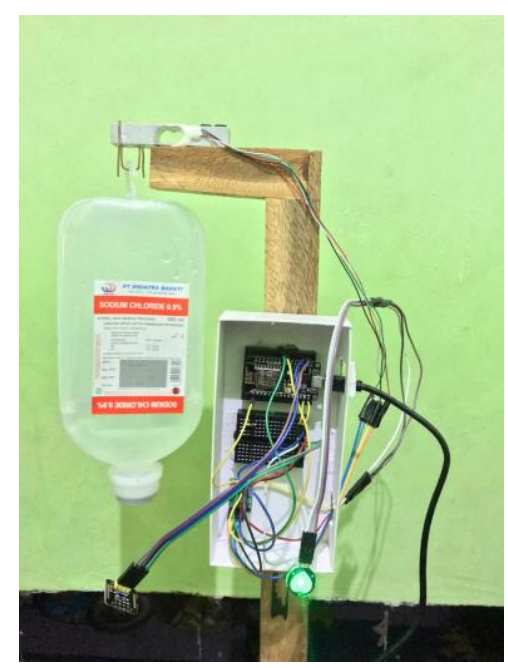

Gambar 7. Implementasi hardware

Gambar 7. Merupakan rangkaian alat system monitoring infus dan kondisi pasien yang sedang dirawat. 


\subsection{Pengujian Sensor Berat}

Pengujian sensor berart (load cell) menggunakan serial monitor untuk melihat apakah terjadi error atau tidak, dengan meletakkan berat infus terhadap sensor tersebut untuk dapat melihat sisa berat kadar infus. Jika keluar range angka dalam gram maka sensor bekerja. Adapaun pengujian ditunjukkan pada Gambar 8.

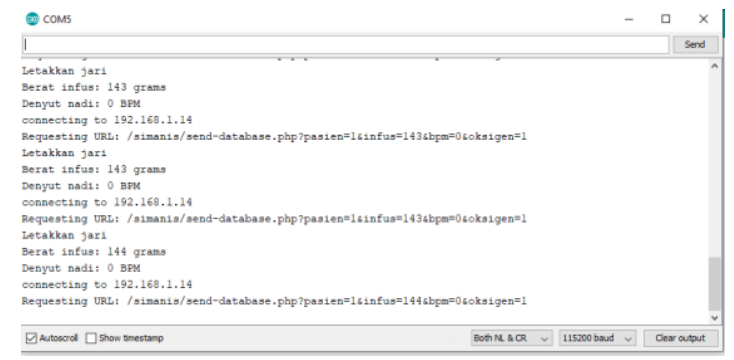

Gambar 8. Pengujian sensor berat

Gambar 8 merupakan hasil pengujian dari sensor berat menggunakan serial monitor yang dimana disana sudah terlihat bahwa sensor berat berhasil mendeteksi berat kadar infus dengan keluarnya nilai range berupa satuan gram.

\subsection{Pengujian sensor heart rate}

Pengujian Heartrate sensor menggunakan serial monitor untuk melihat apakah terjadi error atau tidak, dengan meletakkan tangan kita diatas sensor tersebut untuk dapat melihat data denyut nadi pasien. Jika keluar range angka dalam BPM (beats per minute) maka sensor bekerja. Adapaun pengujian ditunjukkan pada Gambar 9.

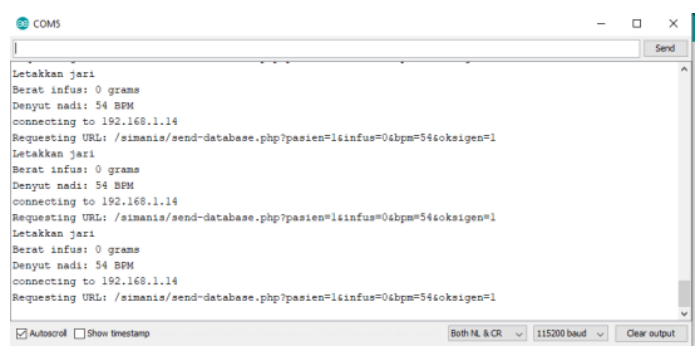

Gambar 9. Pengujian Sensor Heart Rate

Gambar 9 merupakan hasil pengujian dari sensor heart rate menggunakan serial monitor yang dimana disana sudah terlihat bahwa sensor heart rate berhasil mendeteksi kondisi pasien sedang dalam berapa BPM untuk kondisi denyut nadi dan detak jantungnya.

\subsection{Pengujian Temperature sensor}

pengujian Heartrate sensor menggunakan serial monitor untuk melihat apakah terjadi error atau tidak, dengan meletakkan jari kita diatas sensor tersebut untuk dapat melihat kadar oksigen pasien. Jika keluar range angka dalam persen maka sensor bekerja. Adapaun pengujian ditunjukkan pada Gambar 10.

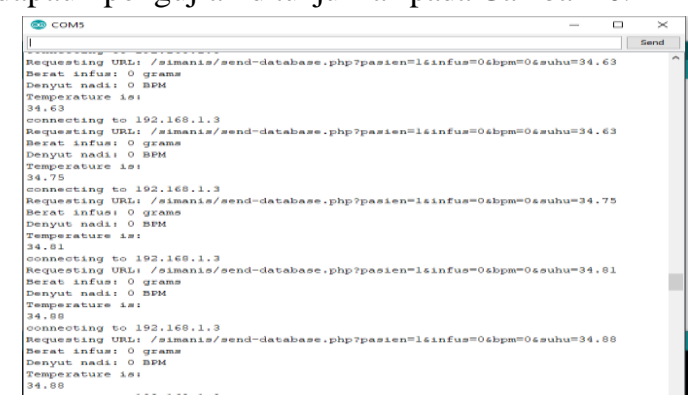

Gambar 10. Pengujian Temperatuer sensor

Gambar 10 merupakan hasil pengujian dari Temperatuer sensor menggunakan serial monitor yang dimana disana sudah terlihat bahwa sensor Temperatuer sensor berhasil mendeteksi suhu badan pasien, dengan keluarnya nilai range berupa satuan persen.

\subsection{Tabel pengujian sensor}

Dari hasil pengujian diatas kita sudah mendapatkan hasil dari data uji masing-masing alat, sebagaimana hasil tertera pada tabel 1 .

Tabel 1. Hasil uji semua sensor

\begin{tabular}{|c|c|c|}
\hline No. & Nama Alat & Hasil Uji \\
\hline 1. & Load Cell Sensor & Berhasil \\
\hline 2. & Heart Rate Sensor & Berhasil \\
\hline 3. & Temperatuer sensor & Berhasil \\
\hline
\end{tabular}

Tabel 1. Merupakan hasil uji semua sensor apakah bekerja dengan baik atau tidak, namun disana sudah jelas bahwa satu sensor tidak dapat berkerja dengan baik atau tidak dapat mendeteksi keadaan pasien.

\subsection{Tabel pengujian sensor berat}

Dari hasil pengujian diatas kita sudah mendapatkan hasil dari data uji masing-masing alat, sebagaimana hasil tertera pada tabel 2 .

Tabel 2. Uji Sensor Berat

\begin{tabular}{|c|c|c|c|}
\hline No. & $\begin{array}{c}\text { Nilai } \\
\text { Berat } \\
\text { Infus Real }\end{array}$ & $\begin{array}{c}\text { NIlai } \\
\text { Berat } \\
\text { Infus } \\
\text { Sensor }\end{array}$ & $\begin{array}{c}\text { Prosesntase } \\
\text { Sensor }\end{array}$ \\
\hline 1. & 150 & 144 & $4 \%$ \\
\hline 2. & 150 & 143 & $4,67 \%$ \\
\hline 3. & 150 & 140 & $6,67 \%$ \\
\hline 4. & 150 & 139 & $7,3 \%$ \\
\hline 5 & 150 & 137 & $8,67 \%$ \\
\hline
\end{tabular}

Tabel 2. merupakan tabel pengujian sensor berat dengan 5 data pengujian dari sensor, dimana dengan nilai range yang berbeda-beda. Tabel pengujian dilakukan untuk mencari nilai prosentase rata rata 
nilai data dari yang sensor hasilkan. Dengan telah dilakukan perhitungan prosesntase error sensor, maka dapat di hasilkan, prosentase error rata-rata sensor berat (load cell) menujukkan hasil $=6,626 \%$, sedangkan untuk nilai prosentase error tertinggi menujukkan hasil $=8,67 \%$

\subsection{Tabel pengujian sensor Heart Rate}

Dari hasil pengujian diatas kita sudah mendapatkan hasil dari data uji masing-masing alat, sebagaimana hasil tertera pada tabel 3.

Tabel 3. Uji Sensor Heart Rate

\begin{tabular}{|c|c|c|c|}
\hline No. & $\begin{array}{c}\text { Nilai Bpm } \\
\text { Standar }\end{array}$ & $\begin{array}{c}\text { NIlai Bpm } \\
\text { Pasien }\end{array}$ & $\begin{array}{c}\text { Prosesntase } \\
\text { Sensor }\end{array}$ \\
\hline 1. & 100 & 91 & $9 \%$ \\
\hline 2. & 100 & 93 & $7 \%$ \\
\hline 3. & 100 & 90 & $10 \%$ \\
\hline 4. & 100 & 94 & $6 \%$ \\
\hline 5 & 100 & 95 & $5 \%$ \\
\hline
\end{tabular}

Tabel 3. merupakan tabel pengujian sensor heart rate dengan 5 data pengujian dari sensor, dimana dengan nilai range yang berbeda-beda. Tabel pengujian dilakukan untuk mencari nilai prosentase rata rata nilai data dari yang sensor hasilkan, Dengan telah dilakukan perhitungan prosesntase error sensor, maka dapat di hasilkan, prosesntase error rata-rata sensor heart rate menujukkan hasil $=7,4 \%$, sedangkan untuk nilai prosesntase error tertinggi menujukkan hasil $=10 \%$

\subsection{Tabel pengujian sensor Temperature}

Dari hasil pengujian diatas kita sudah mendapatkan hasil dari data uji masing-masing alat, sebagaimana hasil tertera pada tabel 4.

Tabel 4. Uji Sensor Temperature

\begin{tabular}{|c|c|c|c|}
\hline No. & $\begin{array}{c}\text { Nilai Suhu } \\
\text { Standar }\end{array}$ & $\begin{array}{c}\text { NIlai Bpm } \\
\text { Pasien }\end{array}$ & $\begin{array}{c}\text { Prosesntase } \\
\text { Sensor }\end{array}$ \\
\hline 1. & 36 & 33,88 & $5,89 \%$ \\
\hline 2. & 36 & 35,12 & $2,44 \%$ \\
\hline 3. & 36 & 34,04 & $5,44 \%$ \\
\hline 4. & 36 & 33,48 & $7 \%$ \\
\hline 5 & 36 & 34,29 & $4.75 \%$ \\
\hline
\end{tabular}

Tabel 4. merupakan tabel pengujian sensor suhu badan dengan 5 data pengujian dari sensor, dimana dengan nilai range yang berbeda-beda. Tabel pengujian dilakukan untuk mencari nilai prosentase rata rata nilai data dari yang sensor hasilkan, Dengan telah dilakukan perhitungan prosesntase error sensor, maka dapat di hasilkan, prosesntase error rata-rata sensor heart rate menujukkan hasil $=5,104 \%$, sedangkan untuk nilai prosesntase error tertinggi menujukkan hasil $=7 \%$

\subsection{Tabel pengujian fungsional}

Dari hasil pengujian diatas kita sudah mendapatkan hasil dari data uji masing-masing halaman monitoring dan tombol button nya, sebagaimana hasil tertera pada tabel 5 .

Tabel 5. Hasil Uji Monitoring

\begin{tabular}{|c|c|c|c|}
\hline \multirow{2}{*}{ No. } & Item Uji & \multicolumn{2}{|c|}{ Hasil Uji } \\
\cline { 3 - 4 } 1. & Berhasil & Gagal \\
\hline & $\begin{array}{c}\text { Malama } \\
\text { Utama }\end{array}$ & $\sqrt{ }$ & - \\
\hline 2. & $\begin{array}{c}\text { Halaman } \\
\text { Riwayat Data }\end{array}$ & $\sqrt{ }$ & - \\
\hline 3. & $\begin{array}{c}\text { Halam Tambah } \\
\text { Data dan Edit }\end{array}$ & $\sqrt{ }$ & - \\
\hline 4. & Button Beranda & $\sqrt{ }$ & - \\
\hline 5. & $\begin{array}{c}\text { Button History } \\
\text { Data }\end{array}$ & $\sqrt{ }$ & - \\
\hline 6. & $\begin{array}{c}\text { Button Data } \\
\text { Pasien }\end{array}$ & $\sqrt{ }$ & - \\
\hline 7. & $\begin{array}{c}\text { Button Pilih } \\
\text { Pasien }\end{array}$ & $\sqrt{ }$ & - \\
\hline 8. & $\begin{array}{c}\text { Button Pencarian } \\
\text { Pasien }\end{array}$ & $\sqrt{ }$ & - \\
\hline 9. & $\begin{array}{c}\text { Button show } \\
\text { entries data }\end{array}$ & $\sqrt{ }$ & - \\
\hline 10. & $\begin{array}{c}\text { Button Prev / } \\
\text { Next data }\end{array}$ & $\sqrt{ }$ & - \\
\hline 11. & Button Edit & $\sqrt{ }$ & - \\
\hline 12. & Button Hapus & $\sqrt{ }$ & - \\
\hline 13. & $\begin{array}{c}\text { Form Tambah } \\
\text { data pasien }\end{array}$ & $\sqrt{ }$ & - \\
\hline 14. & $\begin{array}{c}\text { Button tambah } \\
\text { data }\end{array}$ & $\sqrt{ }$ & - \\
\hline
\end{tabular}

\subsection{Tabel pengujian browser}

Dari hasil pengujian diatas kita sudah mendapatkan hasil dari data uji masing-masing halaman monitoring dan tombol button nya, dan sekarang ini hasil pengujian funsgional webseit dapat berjalan di browser mana saja sebagaimana hasil tertera pada tabel 6 .

Tabel 6 Uji Browser

\begin{tabular}{|c|c|c|c|c|}
\hline \multirow{2}{*}{ No. } & Nama & \multirow{2}{*}{ Versi } & \multicolumn{2}{|c|}{ Hasil uji } \\
\cline { 4 - 5 } & Browser & Status & Keterangan \\
\hline 1. & $\begin{array}{c}\text { Brave } \\
\text { Browser }\end{array}$ & 1.10 .97 & $\sqrt{ }$ & Normal \\
\hline 2. & $\begin{array}{c}\text { Google } \\
\text { Chrome }\end{array}$ & 83.0 .4103 .116 & $\sqrt{ }$ & Normal \\
\hline 3. & $\begin{array}{c}\text { Microsoft } \\
\text { Edge }\end{array}$ & 83.0 .478 .61 & $\sqrt{ }$ & Normal \\
\hline
\end{tabular}




\subsection{Tabel peujian user}

Pengujian pada user atau kuisioner dilakukan untuk mengetahui kepuasan pengguna dalam mengimplementasikan prototype system monitoring infus dan kondisi pasien yang sedang dirawat dari tampilan website, dan respond kemudahan menggunakan website dan prototype alat. Pengujian pengguna di lakukan kepada 5 orang responden. Hasil dari pengujian pengguna dapat di lihat pada Tabel 7 .

Tabel 7. Uji User

\begin{tabular}{|c|c|c|c|c|}
\hline \multirow{2}{*}{ No. } & \multirow{2}{*}{ Pertanyaan } & \multicolumn{3}{|c|}{ Respon Pengguna } \\
\hline & & Baik & Cukup & Kurang \\
\hline 1 & $\begin{array}{l}\text { Bagaimana } \\
\text { tampilan } \\
\text { website } \\
\text { monitoring? }\end{array}$ & 3 & 2 & - \\
\hline 2 & $\begin{array}{c}\text { Bagaimana } \\
\text { Sistem Kerja } \\
\text { Alat? } \\
\end{array}$ & 4 & 1 & - \\
\hline 3 & $\begin{array}{c}\text { Apakah } \\
\text { website mudah } \\
\text { dipahami? }\end{array}$ & 5 & - & - \\
\hline & Total & 12 & 3 & - \\
\hline
\end{tabular}

\section{KESIMPULAN DAN SARAN}

\subsection{Kesimpulan}

Kesimpulan diambil dari hasil pengujian yang telah dilakukan pada bab 4. Berdasarkan beberapa pengujian yang telah dilakukan didapatkan kesimpulan :

1. Hasil pengujian fungsional menunjukkan hasil $100 \%$, artinya semua fitur program dapat berjalan sesuai dengan fungsinya.

2. Hasil pengujian alat menunjukkan hasil $70 \%$, dikarenakan ada satu sensor yang masih tidak bisa bekerja sesuai fungsinya.

3. Hasil pengujian dari Load Cell sensor, prosentase error rata-rata sensor berat (load cell) menunjukkan nilai $=6,626 \%$, sedangkan untuk nilai prosentase error tertinggi menunjukkan nilai $=8,67 \%$

4. Hasil pengujian dari Heart Rate sensor, prosentase error rata-rata sensor heart rate menunjukkan nilai $=7,4 \%$, sedangkan untuk nilai prosentase error tertinggi menunjukkan nilai $=10 \%$

5. Hasil pengujian dari Temperature sensor, prosentase error rata-rata sensor heart rate menunjukkan nilai $=5,104 \%$, sedangkan untuk nilai prosentase error tertinggi menunjukkan nilai $=7 \%$
6. Dari pengujian sistem, sistem dapat di jalankan pada sistem operasi Windows.

7. Dari pengujian fungsional sistem, sistem dapat di jalankan pada 3 browser berbeda. Antara lain : Brave Browser, Google Chrome, Microsoft Egde

8. Dari pengujian sistem dapat berjalan dengan baik menggunakan bahasa pemrograman PHP, MySQL dan PhpMyadmin sebagai database

\subsection{Saran}

Saran berisikan hal - hal apa yang harus diperbaiki dari aplikasi dan alat yang saya kembangkan lebih lanjut dengan tujuan agar hasil yang dicapai lebih maksimum. Berdasarkan penelitian yang telah dilakukan, maka penulis dapat memberikan saran-saran untuk pengembangan selanjutnya antar lain :

1. Memberikan notifikasi berupa email apabila terdeteksi kondisi pasien sedang kritis.

2. Pemilihan sensor-sensor yang tepat untuk dikembangkan.

3. Memperkuat system keamanan pada system

4. Keterbatasan alat sehingga pengujian tidak dapat dilakukan dengan jumlah yang banyak

\section{DAFTAR PUSTAKA}

[1] Idris Adam. "Efektifitas Sistem Informasi PelaporanMonitoring dan Evaluasi (eControlling) pada Bagian Evluasi Pembangunan SekretariatDaerah Kota Bontang".http://ar.mian.fisipunmul.ac.id/site/wp content/uploads/2016/02/3.\%20artikel_ejournal _Nur\%20Ahsani\%20Maghfiro h\%20(02-16-1601-12-44).pdf.(2016)

[2] Priyanto Wenda."Sistem Informasi Monitoring Perkuliahan Berbasis Web di STMIK SINAR NUSANTARA SURAKARTA". 68 http://p3m.sinus.ac.id/jurnal/index.php/TIKomS iN/article/view/194/172. ( 1 November 2015).

[3] Risnandar Erdi."Pembuatan Aplikasi Sistem Informasi Monitoring Kegiatan Mahasiswa Berbasis Web dan Android Clien". http://lib.unnes.ac.id/22122/1/4112312020s.pdf(2015)

[4] Joseph Dedy Irawan, Fourry Handoko, Emmalia Adriantatri, Suryo Adi Wibowo, Yosep Agus Pranoto. "uang Kuliah Pintar Pemantau Tingkat Efektivitas Pembelajaran Yang Dapat Mendeteksi Mahasiswa Bosan Dan Mengantuk".http://eprints.itn.ac.id/3405/1/244973-4039-1-10 20190131\%281\%29.pdf. 2 Februari 2019 